\title{
Micropropagation of Physalis peruviana L. ${ }^{1}$
}

\author{
Lilian Marcia Santana Mascarenhas ${ }^{2}$, \\ José Raniere Ferreira de Santana², Alone Lima Brito ${ }^{2}$
}

\section{ABSTRACT}

Physalis peruviana L. (Solanaceae) is an herbaceous fruit-bearing species that has been gaining market acceptance due to its nutritional and medicinal potential. The main limitations to its cultivation are the short reproductive cycle, the susceptibility of the fruits to pests and the lack of information about the crop management. Hence, studies are necessary to develop strategies for its propagation. This study aimed to evaluate the effects of 6-benzylaminopurine (BAP) and explants on the morphogenetic potential of $P$. peruviana, as well as to establish a protocol for the micropropagation of the species via direct organogenesis. To evaluate the morphogenesis, cotyledonary node, cotyledon, leaf, epicotyl, hypocotyl and root explants were inoculated in Murashige \& Skoog culture medium with half the normal concentration of salts and supplemented with cytokinin BAP $(0.00 \mu \mathrm{M}, 2.22 \mu \mathrm{M}, 4.44 \mu \mathrm{M}, 6.66 \mu \mathrm{M}$ or $8.88 \mu \mathrm{M})$, plus $30 \mathrm{~g} \mathrm{~L}^{-1}$ of sucrose and $7 \mathrm{~g} \mathrm{~L}^{-1}$ of agar. Aiming at a direct production of shoots, the cotyledonary node explant was submitted to $0.00 \mu \mathrm{M}$, $2.22 \mu \mathrm{M}, 4.44 \mu \mathrm{M}, 6.66 \mu \mathrm{M}, 8.88 \mu \mathrm{M}, 13.32 \mu \mathrm{M}, 17.76 \mu \mathrm{M}$ or $22.20 \mu \mathrm{M}$ of BAP. The obtained shoots were tested regarding their rooting potential in media with and without the addition of activated charcoal and then were transferred for acclimatation. The cotyledonary node and leaf explants were the most efficient sources for the regeneration of shoots via direct and indirect organogenesis, respectively. The most significant results for direct shoot production were obtained with $12.50 \mu \mathrm{M}$ of BAP. These shoots were successfully rooted in vitro in medium without activated charcoal, and the microplants acclimated in vegetable earth attained $100 \%$ of survival after 90 days of acclimatation.

KEYWORDS: Organogenesis, 6-benzylaminopurine, tissue culture.

\section{INTRODUCTION}

Physalis peruviana L. (Solanaceae) is an herbaceous fruit-bearing plant with a short cycle, native to the Andes Mountains. Nowadays, its center of greatest biodiversity is Mexico, but Colombia is the leading producer and exporter of the fruit and

\section{RESUMO}

\section{Micropropagação de Physalis peruviana $\mathrm{L}$.}

Physalis peruviana L. (Solanaceae) é uma frutífera herbácea, que vem se consolidando no mercado em virtude de suas potencialidades nutricionais e medicinais. As limitações à sua produção são o ciclo reprodutivo curto, o acometimento dos frutos por pragas e a carência de estudos, o que justifica a busca de estratégias para a sua propagação. Objetivou-se avaliar os efeitos de 6-benzilaminopurina (BAP) e explantes no potencial morfogênico de P. peruviana, bem como estabelecer um protocolo para a micropropagação da espécie via organogênese direta. Para avaliar a morfogênese, explantes (nó cotiledonar, cotilédone, folha, epicótilo, hipocótilo e raiz) foram inoculados em meio de cultura Murashige \& Skoog com metade das concentrações salinas e suplementado com a citocinina BAP $(0,00 \mu \mathrm{M} ; 2,22 \mu \mathrm{M} ; 4,44 \mu \mathrm{M} ; 6,66 \mu \mathrm{M}$; ou $8,88 \mu \mathrm{M})$, acrescido de $30 \mathrm{~g} \mathrm{~L}^{-1}$ de sacarose e $7 \mathrm{~g} \mathrm{~L}^{-1}$ de ágar. Visando à produção de brotos via direta, o explante nó cotiledonar foi submetido a $0,00 \mu \mathrm{M}$; $2,22 \mu \mathrm{M} ; 4,44 \mu \mathrm{M} ; 6,66 \mu \mathrm{M} ; 8,88 \mu \mathrm{M} ; 13,32 \mu \mathrm{M} ; 17,76 \mu \mathrm{M}$; ou 22,20 $\mu \mathrm{M}$ de BAP. Os brotos obtidos foram submetidos ao enraizamento em meios com e sem adição de carvão ativado e, posteriormente, transferidos para aclimatização. Verificou-se que o nó cotiledonar e a folha foram as fontes de explantes mais eficientes para a regeneração dos brotos via organogênese direta e indireta, respectivamente. Os resultados mais significativos para a produção de brotos via direta foram obtidos com $12,50 \mu \mathrm{M}$ de BAP. Estes brotos foram enraizados in vitro em meio isento de carvão, e as microplantas aclimatizadas em terra vegetal alcançaram $100 \%$ de sobrevivência aos 90 dias da aclimatização.

PALAVRAS-CHAVE: Organogênese, 6-benzilaminopurina, cultura de tecidos.

its by-products (Rufato et al. 2008). The species has also been attracting scientific interest due to its chemical composition, which has been found to be rich in phytosterols, vitanolids, carotenoids, phenolic compounds, physalins (Puent et al. 2011), ascorbic acid, vitamin A, iron and phosphorus (Velasquez et al. 2007), as well as for its important biological 
activities, such as antibiotic, antioxidant, anticancer and anti-inflammatory effects (Muniz et al. 2015).

The $P$. peruviana propagation can be asexual, through cuttings, or sexual, through seeds (Chaves et al. 2005). Although propagation with seeds is advantageous due to the large number of seeds per fruit, high germination rates and high genetic variability, the cultivation by seeds in the field has certain limitations for the pharmacology industry and for the production of seedlings due to the plants susceptibility to pests and diseases and low production of secondary metabolites (Oliveira et al. 2013).

In vitro studies conducted with $P$. peruviana have demonstrated that tissue culture techniques are an option for the production of seedlings (Chaves et al. 2005, Rodrigues et al. 2013, Ramar et al. 2014, Yücesan et al. 2015), along with the use of synthetic seeds obtained from nodal segments (Yücesan et al. 2015). However, because of the variable responses obtained by these researchers, adjustments to the existing protocols are needed to assure a more efficient propagation.

Micropropagation allows obtaining a large number of plants in a short time frame and with less space, with the added advantages of good phytosanitary quality, homogeneity of seedlings and high genetic fidelity (Carvalho et al. 2013). This technique can be performed by organogenesis or embryogenesis, which occur by two distinct routes: indirect and direct (Grattapaglia \& Machado 1998). In indirect organogenesis, the explant is induced to form a callus with the subsequent regeneration of adventitious buds, while the direct route involves the development of buds directly from the explant tissue.

Micropropagation consists of four steps: establishment, multiplication, rooting and acclimation (Rout et al. 2006). Considering the complexity of the morphogenetic process, which involves factors such as genotype, source and physiological condition of the explant, culture medium, $\mathrm{pH}$, luminosity and combination of growth regulators (Luciani et al. 2006), the success of each step depends on the establishment of specific protocols.

The cytokinin 6-benzylaminopurine (BAP) has been shown effective in the propagation of various species, for shoot multiplication and induction of adventitious buds, and is the method used with approximately $60 \%$ of the culture media (Grattapaglia \& Machado 1998). Studies performed with P. peruviana by Chaves et al. (2005), Muniz et al. (2013), Rodrigues et al. (2013) and Yucesan et al. (2015) have confirmed this information, demonstrating that BAP is the best regulator for the in vitro regeneration of shoots of this species, although there is still divergence regarding the most efficient concentrations.

In light of this scenario, this study aimed to evaluate the effects of BAP concentrations and varied explant types on the morphogenetic potential of $P$. peruviana, as well as to establish a protocol for its micropropagation via direct organogenesis.

\section{MATERIAL AND METHODS}

The plants were established in vitro from dried seeds of Physalis peruviana L. supplied by the Universidade Estadual de Feira de Santana, in Feira de Santana, Bahia state, Brazil, from October 2016 to April 2018.

The seeds were disinfested by immersion in $70 \%$ alcohol for $30 \mathrm{sec}$ and then sodium hypochlorite $\mathrm{NaClO}$ (2.5\% active chlorine) plus two drops of detergent for $15 \mathrm{~min}$, followed by washing four times with sterile distilled water. Then they were seeded in flasks containing $60 \mathrm{~mL}$ of MS (Murashige \& Skoog 1962) nutritive medium supplemented with $30 \mathrm{~g} \mathrm{~L}^{-1}$ of sucrose and $7 \mathrm{~g} \mathrm{~L}^{-1}$ of agar. The $\mathrm{pH}$ was adjusted to 5.8 and the flasks were sterilized by autoclaving at $121^{\circ} \mathrm{C}$, for $15 \mathrm{~min}$.

The experimental design was completely randomized, using MS medium with three salt concentrations: complete MS, MS $3 / 4$ (25\% reduction of salts) and MS $1 / 2$ (50\% reduction of salts). Each treatment was composed of five repetitions, with four samples each. The germination (radicle emission) was evaluated daily and, at the end of 30 days, the total number of germinated seeds was tallied.

The explants (cotyledon, leaf, cotyledonary node, epicotyl, hypocotyl and root), with approximate length of $1.0 \mathrm{~cm}$, obtained from the plants germinated in vitro with age of 30 days, were individualized in a laminar flow cabinet and inoculated in test tubes (25 mm x $150 \mathrm{~mm}$ ) containing $15 \mathrm{~mL}$ of MS 1/2 supplemented with $30 \mathrm{~g} \mathrm{~L}^{-1}$ of sucrose, $7 \mathrm{~g} \mathrm{~L}^{-1}$ of agar and varying concentrations of BAP $(0.00 \mu \mathrm{M}$, $2.22 \mu \mathrm{M}, 4.44 \mu \mathrm{M}, 6.66 \mu \mathrm{M}$ or $8.88 \mu \mathrm{M})$. The experimental design was completely randomized, in a $6 \times 5$ factorial arrangement (explant type $\times$ BAP concentration), with five repetitions of four samples 
each. The explants were inoculated in the horizontal position on the medium surface (one explant per tube).

After 30 days, the following parameters were determined: percentage of explants with calli, explant area covered by calli $(25 \%, 50 \%, 75 \%$ or $100 \%$ ), number of shoots per explant produced by indirect organogenesis, number of shoots per explant produced by direct organogenesis and percentage of explants forming shoots by direct organogenesis.

To determine the conditions to obtain the best regeneration rate by direct organogenesis, cotyledonary node explants were submitted to BAP concentrations $(0.00 \mu \mathrm{M}, 4.44 \mu \mathrm{M}, 8.88 \mu \mathrm{M}$, $13.32 \mu \mathrm{M}, 17.76 \mu \mathrm{M}$ or $22.20 \mu \mathrm{M})$. The experimental design was completely randomized, where each treatment was composed of five repetitions, with four samples each. The explants were inoculated in the horizontal position on the medium surface (one explant per tube). After 30 days, the parameters number of shoots per explant produced by direct organogenesis and percentage of explants forming shoots by direct organogenesis were evaluated.

Shoots with 30 days of age obtained by direct organogenesis were individualized in test tubes containing $15 \mathrm{~mL}$ of MS $1 / 2$ medium with or without $1 \mathrm{~g} \mathrm{~L}^{-1}$ of activated charcoal. The experimental design was completely randomized, with six repetitions per treatment and five samples each. After culture for 30 days, the percentage of microplants with roots was observed.

The microplants rooted in vitro were transplanted to $500 \mathrm{~mL}$ plastic cups containing vegetable earth + vermiculite $(2: 1)$ or vegetable earth alone, after which $50 \%$ of the microplants were covered with transparent plastic cups and $50 \%$ were exposed directly to the environment in a greenhouse. The experimental design was completely randomized, in a $2 \times 2$ factorial arrangement (substrate $\mathrm{x}$ type of protection), composed of four treatments, with five repetitions of three samples each, arranged in a plastic tray with $500 \mathrm{~mL}$ of water, replenished as needed. The survival percentage of the microplants was determined at 90 days after transfering to the $e x$ vitro condition

During the establishment, multiplication and rooting steps, the cultures were kept in a growth room at a temperature of $25 \pm 3{ }^{\circ} \mathrm{C}$, photoperiod of $16 \mathrm{~h}$ and photosynthetically active radiation of $60 \mu \mathrm{mol} \mathrm{m}{ }^{-2} \mathrm{~s}^{-1}$, supplied by white fluorescent lamps, while, in the acclimatation step, the plants were kept under a sombrite screen with $70 \%$ luminosity rating.

The data were checked for normality and homogeneity of variance and, when satisfying these requirements, were submitted to analysis of variance (Anova) using the Sisvar software (Ferreira 2011), and the means were compared using the Tukey test at $5 \%$ of probability for qualitative data or by linear regression for quantitative data. The data expressed in percentage were transformed by computing arcsine $\sqrt{ } \mathrm{x} / 100$.

\section{RESULTS AND DISCUSSION}

The germination began on the fifth day after the inoculation of the seeds in vitro for the culture media MS $3 / 4$ and MS $1 / 2$, and on the seventh day for MS, the period during which the highest germination rate occurred in all the tested media (Figure 1). On the 14th day after seeding, $100 \%$ of the seeds in MS $1 / 2$ and $\mathrm{MS} 3 / 4$ had germinated, while, in MS, $87 \%$ of the seeds germinated after this interval, demonstrating the high capacity of $P$. peruviana to germinate in vitro in more diluted media (Figure 1). Therefore, for the rest of the experiments, MS $1 / 2$ was used to reduce the purchasing costs of macro and micronutrients. The use of MS medium in more diluted compositions was reported for multiplication of $P$. peruviana by Chaves et al. (2005) and Rodrigues et al. (2013), who used MS $3 / 4$ and MS $1 / 2$, respectively.

The analysis of variance showed that the explant $x$ BAP interaction was significant $(p \leq 0.05)$ for the variables percentage of explants with calli, area covered by calli and number of shoots per

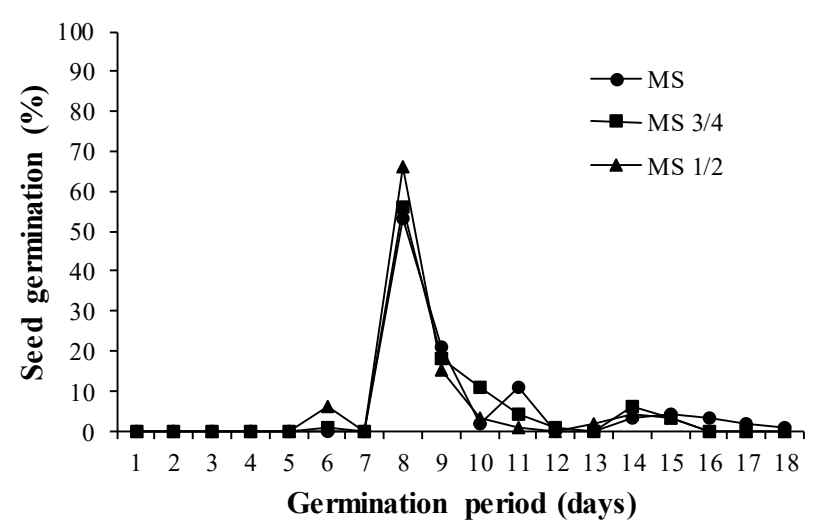

Figure 1. Germination frequency of Physalis peruviana L. seeds in Murashige \& Skoog (MS) culture medium with different salt concentrations. 
explant produced by direct organogenesis. For the percentage of explants forming shoots by direct organogenesis and number of shoots per explant produced by indirect organogenesis, only the isolated effect of explant type was significant $(\mathrm{p} \leq 0.05)$.

In the culture medium without growth regulator, there were no significant differences for leaf, cotyledonary node, epicotyl and hypocotyl explants, but these all differed in relation to the cotyledon and root explants, which had the lowest average percentage of explants with calli values (Table 1). The occurrence of callogenesis in the absence of growth regulators suggests that a balance exists between endogenous auxin and cytokinin in the tested tissues. This balance induces cell proliferation and promotes the transformation of differentiated and specialized somatic cells into dedifferentiated cells (Nogueira et al. 2007).

In the culture media containing BAP, the leaf and cotyledonary node tissues performed differently in the calli formation at all tested concentrations, confirming the importance of testing different types of explants from the same plant (Table 1).

In the root explants, callogenesis only occurred at the BAP concentration of $6.66 \mu \mathrm{M}$, with $15 \%$ of explant response, and the value for the area covered by calli was only $8.75 \%$ (Table 1), suggesting a high cell specialization of the $P$. peruviana roots. The absence of a morphogenetic response in the root tissues of $P$. angulata was demonstrated by Vidal (2008), in tests with different BAP concentrations.
The leaf, cotyledonary node, epicotyl and hypocotyl explants did not differ from each other with respect to the value for the area covered by calli, but were significantly better than the cotyledon explants in the medium without regulator. At the BAP concentration of $4.44 \mu \mathrm{M}$, the leaf explants presented a greater expansion of the area covered with calli $(62.25 \%)$, but at the BAP concentration of $8.88 \mu \mathrm{M}$, they did not differ from the cotyledonary node and hypocotyl explants (Table 1).

The regression analysis for the treatments with BAP revealed a significant result only for the leaf explants, with a rising quadratic mathematical model for percentage of explants with calli, where the maximum estimated value $(95.56 \%)$ was obtained at the BAP concentration of $6.84 \mu \mathrm{M}$ (Figure 2).

There are no reports in the literature of the use of BAP for organogenic induction of calli in the Physalis species. In this study, the results demonstrate that low concentrations of this cytokinin are sufficient to induce a high average percentage of explants with calli in the studied species. The calli produced by the leaf explants were friable and had varied colors (beige, green, brown and white with translucent regions; Figure 3). The texture and morphology of calli vary according to the medium constituents and regulator concentrations (George 2008).

In general, for the variables percentage of explants with calli and area covered by calli, the leaf and cotyledonary node explants had the highest

Table 1. Percentage of explants with calli and explant area covered by calli in Physalis peruviana L. grown in Murashige \& Skoog $1 / 2$ medium with different 6-benzylaminopurine (BAP) concentrations.

\begin{tabular}{|c|c|c|c|c|c|c|}
\hline \multirow{3}{*}{$\mathrm{BAP}(\mu \mathrm{M})$} & \multicolumn{6}{|c|}{ Explants } \\
\hline & \multicolumn{6}{|c|}{ Explants with calli (\%) } \\
\hline & Cotyledon & Leaf & Cotyledonary node & Epicotyl & Hypocotyl & Root \\
\hline 0.00 & $10.00 \mathrm{~b}^{*}$ & $55.00 \mathrm{a}$ & $75.00 \mathrm{a}$ & $75.00 \mathrm{a}$ & $55.00 \mathrm{a}$ & $0.00 \mathrm{~b}$ \\
\hline 2.22 & $95.00 \mathrm{a}$ & $85.00 \mathrm{a}$ & $100.00 \mathrm{a}$ & $80.00 \mathrm{a}$ & $85.00 \mathrm{a}$ & $0.00 \mathrm{~b}$ \\
\hline 4.44 & $45.00 \mathrm{c}$ & $90.00 \mathrm{ab}$ & $95.00 \mathrm{a}$ & $85.00 \mathrm{ab}$ & $60.00 \mathrm{bc}$ & $0.00 \mathrm{~d}$ \\
\hline 6.66 & $75.00 \mathrm{ab}$ & $90.00 \mathrm{a}$ & $85.00 \mathrm{a}$ & $45.00 \mathrm{bc}$ & $60.00 \mathrm{ab}$ & $15.00 \mathrm{c}$ \\
\hline 8.88 & $55.00 \mathrm{~b}$ & $95.00 \mathrm{a}$ & $95.00 \mathrm{a}$ & $25.00 \mathrm{bc}$ & $55.00 \mathrm{~b}$ & $0.00 \mathrm{c}$ \\
\hline \multirow[t]{2}{*}{ CV $(\%)$} & \multicolumn{6}{|c|}{29.25} \\
\hline & \multicolumn{6}{|c|}{ Explant area covered by calli } \\
\hline 0.00 & $2.50 \mathrm{~b}$ & $18.75 \mathrm{a}$ & $35.00 \mathrm{a}$ & $30.00 \mathrm{a}$ & $32.50 \mathrm{a}$ & $0.00 \mathrm{~b}$ \\
\hline 2.22 & $23.75 \mathrm{a}$ & $32.50 \mathrm{a}$ & $37.50 \mathrm{a}$ & $25.00 \mathrm{a}$ & $26.50 \mathrm{a}$ & $0.00 \mathrm{~b}$ \\
\hline 4.44 & $11.25 \mathrm{~b}$ & $66.25 \mathrm{a}$ & $27.50 \mathrm{~b}$ & $32.50 \mathrm{~b}$ & $21.25 \mathrm{~b}$ & $0.00 \mathrm{c}$ \\
\hline 6.66 & $16.25 \mathrm{ab}$ & $32.50 \mathrm{a}$ & $27.50 \mathrm{a}$ & $17.50 \mathrm{ab}$ & $20.00 \mathrm{a}$ & $8.75 \mathrm{c}$ \\
\hline 8.88 & $13.75 \mathrm{bc}$ & $28.75 \mathrm{ab}$ & $41.25 \mathrm{a}$ & $8.75 \mathrm{~cd}$ & $20.00 \mathrm{abc}$ & $0.00 \mathrm{~d}$ \\
\hline CV $(\%)$ & \multicolumn{6}{|c|}{27.15} \\
\hline
\end{tabular}




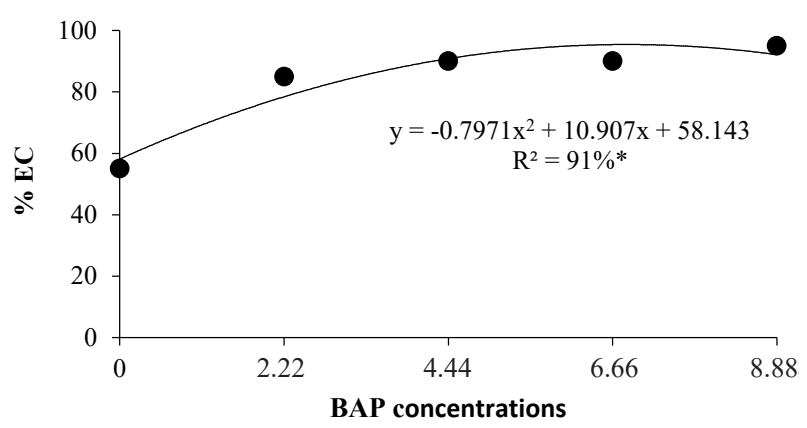

Figure 2. Percentage of leaf explants with calli (\% EC) of Physalis peruviana $\mathrm{L}$. cultured in vitro with different 6-benzylaminopurine (BAP) concentrations.

percentages at all the tested BAP concentrations, but the leaf explants were superior for induction of callogenesis, because they showed a better potential for formation of calli and could be obtained in greater numbers from a single plant.

For percentage of explants with calli by indirect organogenesis (Figure 4), the leaf explants differed from the others, with regeneration of $15.92 \%$ and an average of 0.71 shoots per explant (Table 2). This result is advantageous, considering the larger number of leaf explants that can be obtained from each plant, allowing a high multiplication rate from a single parent plant.

With respect to the variable number of shoots per explant obtained by indirect organogenesis, the cotyledonary node produced higher regeneration rates at all the tested BAP concentrations, if compared to the other explants (Table 3). The regeneration by this route favors the commercial

Table 2. Effect of explant type on the percentage of calli with shoots and number of shoots per explant obtained by indirect organogenesis in explants of Physalis peruviana $\mathrm{L}$.

\begin{tabular}{lcc}
\hline \multicolumn{1}{c}{ Explants } & $\begin{array}{c}\text { Calli with } \\
\text { shoots }(\%)\end{array}$ & $\begin{array}{c}\text { Number of shoots } \\
\text { per explant }\end{array}$ \\
\hline Cotyledon & $0.00 \mathrm{~b}^{*}$ & $0.01 \mathrm{~b}$ \\
Leaf & $15.92 \mathrm{a}$ & $0.71 \mathrm{a}$ \\
Cotyledonary node & $0.00 \mathrm{~b}$ & $0.03 \mathrm{~b}$ \\
Epicotyl & $0.13 \mathrm{~b}$ & $0.01 \mathrm{~b}$ \\
Hypocotyl & $0.13 \mathrm{~b}$ & $0.02 \mathrm{~b}$ \\
Root & $0.00 \mathrm{~b}$ & $0.00 \mathrm{~b}$ \\
\hline $\mathrm{CV}(\%)$ & 4.26 & 14.90 \\
\hline
\end{tabular}

* Means followed by the same lowercase letter in the column do not differ from each other by the Tukey test $(\mathrm{p} \leq 0.05)$.

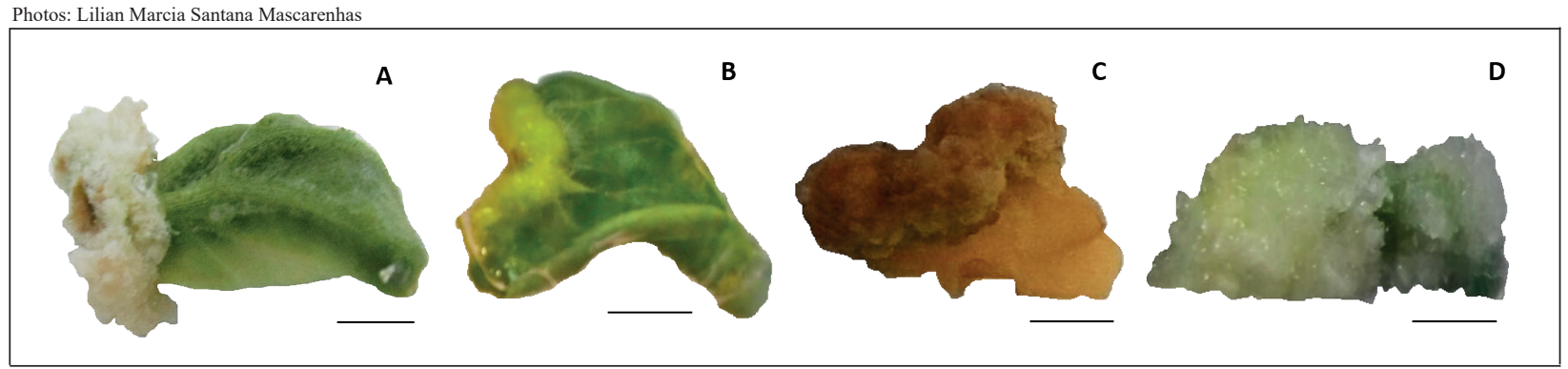

Figure 3. Callogenesis in leaf explants cultured in Murashige \& Skoog $1 \frac{1}{2}$ medium with different 6-benzylaminopurine concentrations. Calli coloration: beige (A), green (B), brown (C), white and translucent in some regions (D). Bar: $1 \mathrm{~cm}$.

Photos: Lilian Marcia Santana Mascarenhas

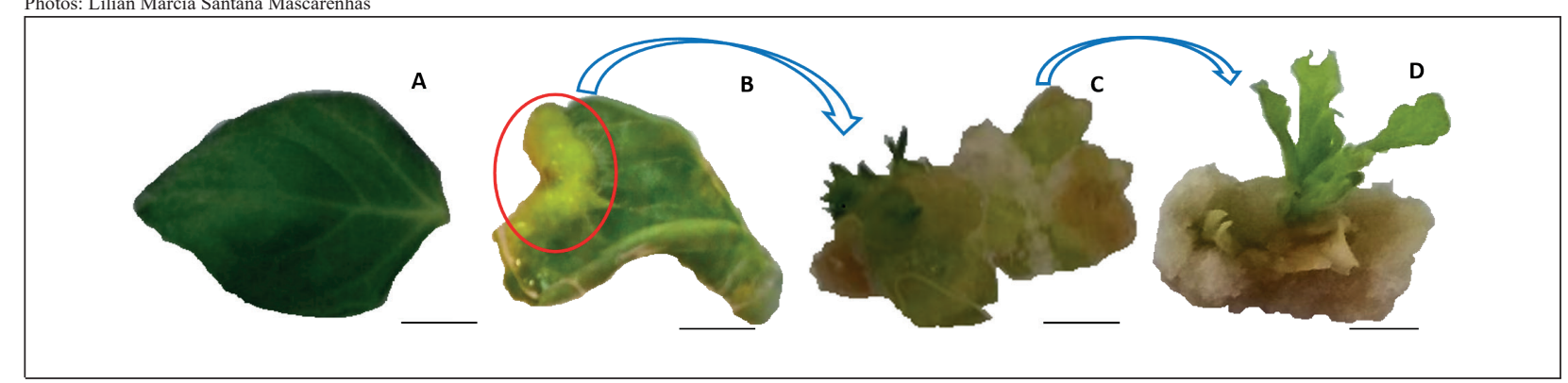

Figure 4. In vitro morphogenesis of leaf explants of Physalis peruviana L. grown in Murashige \& Skoog $1 / 2$ culture medium with different 6-benzylaminopurine (BAP) concentrations. A) leaf explant; B) callogenesis in medium with $4.44 \mu \mathrm{M}$ of BAP; $\mathrm{C}, \mathrm{D})$ indirect organogenesis in medium supplemented with $4.44 \mu \mathrm{M}$ of BAP. Bar: $1 \mathrm{~cm}$. 
Table 3. Average number of shoots per explant by direct organogenesis and percentage of explants with shoots by direct organogenesis in Physalis peruviana L., after growth for 30 days in Murashige \& Skoog $1 / 2$ culture medium, with different 6-benzylaminopurine (BAP) concentrations.

\begin{tabular}{|c|c|c|c|c|c|c|}
\hline \multirow{3}{*}{$\mathrm{BAP}(\mu \mathrm{M})$} & \multicolumn{6}{|c|}{ Explants } \\
\hline & \multicolumn{6}{|c|}{ Number of shoots per explant } \\
\hline & Cotyledon & Leaf & Cotyledonary node & Epicotyl & Hypocotyl & Root \\
\hline 0.00 & $0.00 \mathrm{~b}^{*}$ & $0.00 \mathrm{~b}$ & $2.28 \mathrm{a}$ & $0.05 \mathrm{~b}$ & $0.00 \mathrm{~b}$ & $0.00 \mathrm{~b}$ \\
\hline 2.22 & $0.00 \mathrm{~b}$ & $0.35 \mathrm{~b}$ & $11.05 \mathrm{a}$ & $0.00 \mathrm{~b}$ & $0.00 \mathrm{~b}$ & $0.00 \mathrm{~b}$ \\
\hline 4.44 & $0.10 \mathrm{c}$ & $0.50 \mathrm{c}$ & $13.65 \mathrm{a}$ & $1.85 \mathrm{~b}$ & $0.05 \mathrm{c}$ & $0.00 \mathrm{c}$ \\
\hline 6.66 & $0.05 \mathrm{~b}$ & $0.75 \mathrm{~b}$ & $15.75 \mathrm{a}$ & $0.85 \mathrm{~b}$ & $0.00 \mathrm{~b}$ & $0.00 \mathrm{~b}$ \\
\hline 8.88 & $0.00 \mathrm{~b}$ & $0.00 \mathrm{~b}$ & $23.55 \mathrm{a}$ & $0.00 \mathrm{~b}$ & $0.15 \mathrm{~b}$ & $0.00 \mathrm{~b}$ \\
\hline $\mathrm{CV}(\%)$ & \multicolumn{6}{|c|}{14.00} \\
\hline \multicolumn{7}{|c|}{ Explants with shoots (\%) } \\
\hline 0.00 & $0.00 \mathrm{~b}$ & $0.00 \mathrm{~b}$ & $100.00 \mathrm{a}$ & $5.00 \mathrm{~b}$ & $0.00 \mathrm{~b}$ & $0.00 \mathrm{~b}$ \\
\hline 2.22 & $0.00 \mathrm{~b}$ & $10.00 \mathrm{~b}$ & $100.00 \mathrm{a}$ & $0.00 \mathrm{~b}$ & $0.00 \mathrm{~b}$ & $0.00 \mathrm{~b}$ \\
\hline 4.44 & $5.00 \mathrm{~d}$ & $20.00 \mathrm{bc}$ & $100.00 \mathrm{a}$ & $35.00 \mathrm{~b}$ & $5.00 \mathrm{~cd}$ & $0.00 \mathrm{~d}$ \\
\hline 6.66 & $5.00 \mathrm{~b}$ & $15.00 \mathrm{~b}$ & $100.00 \mathrm{a}$ & $10.00 \mathrm{~b}$ & $0.00 \mathrm{~b}$ & $0.00 \mathrm{~b}$ \\
\hline 8.88 & $0.00 \mathrm{~b}$ & $0.00 \mathrm{~b}$ & $100.00 \mathrm{a}$ & $0.00 \mathrm{~b}$ & $10.00 \mathrm{~b}$ & $0.00 \mathrm{~b}$ \\
\hline CV (\%) & \multicolumn{6}{|c|}{46.85} \\
\hline
\end{tabular}

* Means followed by the same lowercase letter in the row do not differ from each other by the Tukey test $(\mathrm{p} \leq 0.05)$.

scale production of seedlings, because it occurs quickly, with a lower cost and smaller risk of genetic variation (George 2008).

The results of the regression analysis were significant for the cotyledonary node explants, for which a rising linear model was most representative of this variable, indicating that the supply of exogenous BAP in the medium enhanced the multiplication, which reached an average of 23.55 shoots per explant at the BAP concentration of $8.88 \mu \mathrm{M}$ (Figure 5). Likewise, investigating cotyledonary node explants of $P$. minima, Jahirhussain et al. (2016) in MS 1/2 medium and Sheeba et al. (2010) in MS supplemented with $8.88 \mu \mathrm{M}$ of BAP obtained averages of 13.4 and $19.0 \pm 8.59$ shoots per explant, respectively.

Results reported in the literature for the use of cotyledonary node explants from species of the Physalis genus diverge from those found in this study, in relation to the BAP concentration to obtain shoots via direct organogenesis. Chaves et al. (2005) and Rodrigues et al. (2013) observed that the highest numbers of shoots per explant of $P$. peruviana were 1.75 and 3.0 at BAP concentrations of $1.33 \mu \mathrm{M}$ and $5.77 \mu \mathrm{M}$, respectively. Oliveira et al. (2013) obtained the largest shoot production rate $(2.84$ shoots per explant) for $P$. angulate using a BAP concentration of $1.33 \mu \mathrm{M}$. On the other hand, Afroz et al. (2009) in experiments with $P$. minima and Ramasubbu (2009) working with $P$. angulata obtained the best results

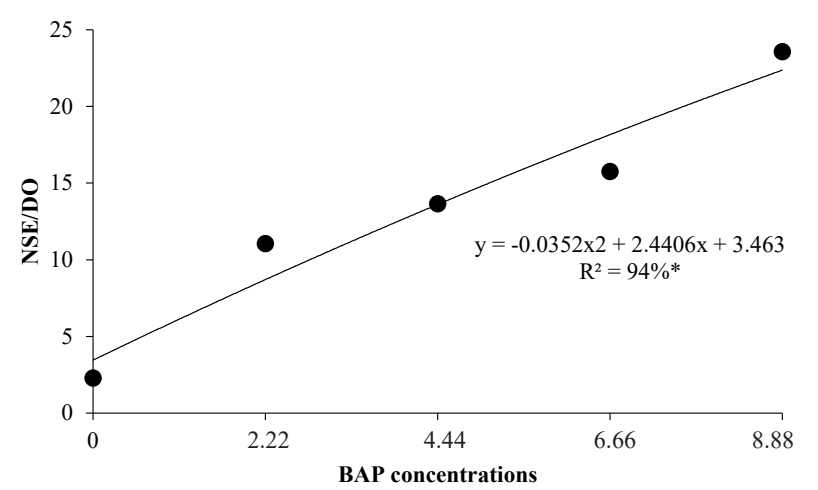

Figure 5. Average number of shoots per explant obtained by direct organogenesis (NSE/DO) from cotyledonary node explants of Physalis peruviana L., after cultivation for 30 days in Murashige \& Skoog $1 / 2$ medium supplemented with different 6-benzylaminopurine (BAP) concentrations.

from cotyledonary node explants with $4.44 \mu \mathrm{M}$ of BAP.

Morphogenetic competence is a complex process and the differences reported in the literature indicate that the concentration of growth regulators, place of excision, type of tissue and genotype may all affect the rate of multiplication and regeneration route of shoots. According to Costa et al. (2015), within the same genus, and even within a single species, the genotypes may respond differently to in vitro morphogenetic processes. 
The cotyledonary node explants were significantly better than the cotyledon, leaf, epicotyl, hypocotyl and root explants at all the tested BAP concentrations, with a maximum of $100 \%$ of explants responsive to direct organogenesis, while the rates for the other explants did not mutually differ, except at the BAP concentration of $4.44 \mu \mathrm{M}$ (Table 3 ).

There were no significant differences for rooting percentages in the treatments with and without activated charcoal. After growth for 30 days, $100 \%$ of the plants in the two treatments had rooted and, in general, the roots were fine, long and branched. These qualities are essential for plants to reach and absorb nutrients and water from the substrate, and thus to survive and develop ex vitro (Freitas et al. 2008, Saini et al. 2013).

There are no reports of rooting of $P$. peruviana in vitro in culture medium without growth regulator. The results found in this study corroborate those of Contreras \& Almeida (2003) and Vidal (2008) for $P$. ixocarpa and $P$. angulata, respectively, both of which rooted without auxin supplementation, suggesting that those species contain high concentrations of endogenous auxin, an important factor to reduce the costs for producing plants in vitro.

The $P$. peruviana plants achieved $100 \%$ of survival at 90 days after transfering in all the tested treatments, demonstrating a high resistance when submitted to transition between in vitro and ex vitro conditions, and suggesting that this step does not pose an obstacle to the micropropagation of the species.

\section{CONCLUSIONS}

1. Tissue culture is a viable alternative for the micropropagation of Physalis peruviana;

2 . The in vitro morphogenetic expression of P. peruviana is influences both by the explant type and BAP concentration;

3. The cotyledonary node and leaf explants are efficient for the regeneration of $P$. peruviana shoots via direct and indirect organogenesis, respectively;

4. The production cost of micropropagated $P$. peruviana seedlings may be reduced by using diluted MS medium and rooting the shoots in medium without growth regulators or activated charcoal;

5. P. peruviana microplants present high survival rates after acclimation.

\section{REFERENCES}

AFROZ, F. et al. In vitro shoot proliferation and plant regeneration of Physalis minima L., a perennial medicinal herb. Bangladesh Journal of Scientific and Industrial Research, v. 44, n. 4, p. 453-456, 2009.

CARVALHO, A. C. P. P. de et al. Panorama da cultura de tecidos no Brasil com ênfase em flores e plantas ornamentais. In: JUNGHANS, T. G.; SOUZA, A. da S. Aspectos práticos da micropropagação de plantas. 2. ed. Brasília, DF: Embrapa, 2013. p. 13-53.

CHAVES, A. C.; SCHUCH, M. W.; ERIG, A. C. Estabelecimento e multiplicação in vitro de Physalis peruviana. Ciência e Agrotecnologia, v. 29, n. 6, p. 12811287, 2005.

CONTRERAS, I.; ALMEIDA, J. Micropropagación del tomatillo (Physalis ixocarpa L.). Revista de la Facultad de Farmacia de la Universidad de los Andes, v. 45, n. 1, p. 61-64, 2003.

COSTA, A. S. da M. et al. Multiplicação in vitro e indução de calos embriogênicos em híbrido de manjericão. Revista Scientia Plena, v. 11, n. 1, p. 1-13, 2015.

FERREIRA, D. F. Sisvar: a computer statistical analysis system. Ciência e Agrotecnologia, v. 35, n. 6, p. 10391042, 2011.

FREITAS, T. A. S.; BARROSO, D. G.; CARNEIRO, J. G. A. Dinâmica de raízes de espécies arbóreas: visão da literatura. Ciência Florestal, v. 18, n. 1, p. 133-142, 2008.

GEORGE, E. F. Plant tissue culture procedure background. In: GEORGE, E. F.; HALL, M. A.; KLERK, G.-J. de. Plant propagation by tissue culture. 3. ed. Dordrecht: Springer, 2008. p. 1-28.

GRATTAPAGLiA, D.; MACHADO, M. A. Micropropagação. In: TORRES, A. C.; CALDAS, L. S.; BUSO, J. A. Cultura de tecidos e transformação genética das plantas. Brasília, DF: Embrapa-SPI/Embrapa-CNPH, 1998. p. 183-260.

JAHIRHUSSAIN, G. et al. In vitro shoot multiplication of Physalis minima L.: an important medicinal herb. Journal of Advanced Applied Scientific Research, v. 1, n. 3, p. 49-58, 2016.

LUCIANI, G. F. et al. Effects of explants and growth regulators in garlic callus formation and plant regeneration. Plant Cell, Tissue and Organ Culture, v. 87, n. 2, p. 139143, 2006.

MUNIZ, J. et al. Crescimento vegetativo e potencial produtivo de fisális. Revista de Ciências Agroveterinárias, v. 14, n. 1, p. 15-23, 2015. 
MUNIZ, J. Micropropagação e aclimatização de Physalis peruviana e Physalis alkekengi. 2013. 70 f. Dissertação (Mestrado em Produção Vegetal) - Universidade do Estado de Santa Catarina, Lages, 2013.

MURASHIGE, T.; SKOOG, F. A revised medium for rapid growth and bioassays with tobacco tissue cultures. Physiologia Plantarum, v. 15, n. 4, p. 473-97, 1962.

NOGUEIRA, R. C. et al. Indução de calos em explantes foliares de murici-pequeno (Byrsonima intermedia A. Juss.). Ciência e Agrotecnologia, v. 31, n. 2, p. 366-370, 2007.

OLIVEIRA, L. M. et al. Estabelecimento in vitro e crescimento inicial de Physalis angulata (Solanaceae). Sitientibus: Ciências Biológicas, v. 13, n. 1, p. 13-17, 2013.

PUENT, L. A. et al. Physalis peruviana Linnaeus, the multiple properties of a highly functional fruit: review. Food Research International, v. 44, n. 7, p. 1733-1740, 2011.

RAMAR, K.; AYYADURAI, V.; ARULPRAKASH, T. In vitro shoot multiplication and plant regeneration of Physalis peruviana L.: an important medicinal plant. International Journal of Current Microbiology and Applied Sciences, v. 3, n. 3, p. 456-464, 2014.

RAMASUBBU, L. R. Micropropagation and estimation of biochemical constituents in Pedalium murex L. and Physalis angulata. International Journal of Environmental Science and Technology, v. 2, n. 4, p. 226-230, 2009.

RODRIGUES, F. A. et al. Diferentes concentrações de sais do meio MS e BAP na multiplicação in vitro de Physalis peruviana. Bioscience Journal, v. 29, n. 1, p. 77-82, 2013.
ROUT, G. R.; MOHAPATRA, A.; JAIN, S. M. Tissue culture of ornamental pot plant: a critical review on present scenario and future prospects. Biotechnology Advances, v. 24, n. 6, p. 531-560, 2006.

RUFATO, L. et al. Aspectos técnicos da cultura da Physalis. Lages: UFPel/Udesc, 2008.

SAINI, S. et al. Auxin: a master regulator in plant root development. Plant Cell Reports, v. 32, n. 6, p. 741-757, 2013.

SHEEBA, E.; PARVATHY, S.; PALANIVEL, S. Direct regeneration from leaves and nodes explantes of Physalis minima L. European Journal of Applied Sciences, v. 2, n. 2, p. 58-61, 2010.

VELASQUEZ, H. J. C.; GIRALDO, O. H. B.; ARANGO, S. S. P. Estudio preliminar de la resistência mecánica a la fractura y fuerza de firmeza para fruta de uchuva (Physalis peruviana). Revista de la Facultad Nacional de Agronomía, v. 60, n. 1, p. 3785-3796, 2007.

VIDAL, J. O. Micropropagação e aclimatização de camapu (Physalis angulata). 2008. 61 f. Dissertação (Mestrado em Agricultura e Sustentabilidade na Amazônia) - Universidade Federal do Amazonas, Manaus, 2008.

YÜCESAN, B. B. et al. Clonal propagation and synthetic seed production from nodal segments of Cape gooseberry (Physalis peruviana L.), a tropical fruit plant. Turkish Journal of Agriculture and Forestry, v. 39, n. 5, p. 797$806,2015$. 